\title{
Attractiveness, athleticism, studiousness, brillance, and wealth*
}

\author{
GARY HODO, CATHRYN WHITFIELD, \\ MAGGIE BURKHALTER, and WARNER WILSON \\ University of Alabama, University, Ala. 35486.
}

Thirteen college males and 13 college females ranked 16 possible combinations of four dichotomous traits: athletic vs non-athletic, studious vs nonstudious, brillant vs average, and wealthy vs not wealthy. Each variable exerted a significant effect $(p<.01)$.

Tannenbaum (1960) examined the preferences of high school students considering dimensions of brilliant vs average, studious vs nonstudious, and athletic vs nonathletic. Studies such as Tannenbaum's can contribute to our understanding of why people like or dislike other people. Such studies may also suggest what qualities a person should cultivate, and/or reveal, to maximize their popularity. The present study replicated Tannenbaum's study with 26 college students and added the dimension of wealthy vs not wealthy.

\section{METHOD}

The Ss were 13 males and 13 females enrolled in introductory psychology. They examined a typed sheet that presented the 16 possible combinations of the four dichotomous traits and assigned a rank of 1 to 16 to each combination.

The 16 ranks assigned by each $\mathrm{S}$ were transformed to $\mathrm{T}$ scores (Walker \& Lev, 1953, p. 480) and the data were then subjected to a 2 by 2 by 2 by 2 by 2 analysis of variance, the five dichotomous variables being male vs female, athletic vs nonathletic. studious vs nonstudious, intelligent vs average, and wealthy vs not wealthy.

\section{RESULTS AND DISCUSSION}

An analysis of variance (Table 1) showed that all four trait dimensions exerted effects significant at least at the .01 level. The mean $\mathrm{T}$ scores given in Table 2 show that an athletic male is preferred over a nonathletic one, a studious male is preferred over a nonstudious one, a brilliant male is preferred over an average one, and a wealthy male is preferred over a not wealthy one by these college students. There were no exceptions to the regularity of these main effects. Differences between the ratings made by men and women were small and nonsignificant. For this reason, the analysis (Table 1) was repeated on the whole sample.

Table 2 includes the results of Tannenbaum's (1960) study for the sake of comparison. The present results agree with those of Tannenbaum only in that they show that being athletic is consistently desirable irrespective of other traits. This result also agrees with that of Horowitz (1967), who found interest in sports correlated with popularity. The present study shows that college students view studiousness as desirable, while

*The first three authors carried out the study while enrolled in a directed research course under the direction of the fourth author.
Table 1

Analysis of Variance Showing the Main Effects of the Four Dichotomous Traits

\begin{tabular}{lrc}
\hline \multicolumn{1}{c}{ Source } & df & \multicolumn{1}{c}{ F } \\
\hline Athleticism & 1 & 81.60 \\
Studiousness & 1 & 107.11 \\
Brilliance & 1 & 61.37 \\
Wealth & 1 & 28.70 \\
Error & 400 & $\mathbf{5 6 . 5 9 )}$ \\
\hline
\end{tabular}

Note-This table omits all nonsignificant (interaction) effects.

Tannenbaum's results indicated that high school students viewed studiousness as undesirable. The present study shows that college students view brilliance as desirable, while Tannenbaum's study showed no main effect of brilliance but an interaction with studiousness, brilliance being viewed as desirable when combined with nonstudiousness and as undesirable when combined with studiousness.

This study is like most studies of personality impression formation in that the $\mathrm{E}$ attributed more or less favorable adjectives to hypothetical third persons. Much has been done on both empirical and theoretical levels (see, for example, Anderson, 1971; Kaplan \&

Table 2

Mean Rank and Rank Order Received by Each Trait Combination

\begin{tabular}{|c|c|c|c|c|c|}
\hline \multirow[b]{2}{*}{$\begin{array}{c}\text { Trait } \\
\text { Combination } \\
\end{array}$} & \multicolumn{2}{|c|}{ Wealthy } & \multicolumn{2}{|c|}{$\begin{array}{c}\text { Not } \\
\text { Wealthy }\end{array}$} & \multirow[b]{2}{*}{$\begin{array}{l}\text { Rank } \\
\text { Order* }\end{array}$} \\
\hline & $\begin{array}{l}\text { Mean } \\
\text { Rank }\end{array}$ & $\begin{array}{l}\text { Rank } \\
\text { Order }\end{array}$ & $\begin{array}{l}\text { Mean } \\
\text { Rank }\end{array}$ & $\begin{array}{l}\text { Rank } \\
\text { Order }\end{array}$ & \\
\hline $\begin{array}{l}\text { Brilliant } \\
\text { Studious } \\
\text { Athletic }\end{array}$ & 2.88 & 1 & 4.38 & 1 & 4 \\
\hline $\begin{array}{l}\text { Average } \\
\text { Studious } \\
\text { Athletic }\end{array}$ & 5.85 & 2 & 8.04 & 4 & 3 \\
\hline $\begin{array}{l}\text { Brilliant } \\
\text { Nonstudious } \\
\text { Athletic }\end{array}$ & 6.19 & 3 & 8.00 & 3 & 1 \\
\hline $\begin{array}{l}\text { Average } \\
\text { Nonstudious } \\
\text { A thletic }\end{array}$ & 9.12 & 6 & 10.38 & 6 & 2 \\
\hline $\begin{array}{l}\text { Brilliant } \\
\text { Studious } \\
\text { Nonathletic }\end{array}$ & 6.42 & 4 & 7.27 & 2 & 8 \\
\hline $\begin{array}{l}\text { Average } \\
\text { Studious } \\
\text { Nonathletic }\end{array}$ & 8.42 & 5 & 10.35 & 5 & 7 \\
\hline $\begin{array}{l}\text { Brilliant } \\
\text { Nonstudious } \\
\text { Nonathletic }\end{array}$ & 10.23 & 7 & 12.62 & 7 & 5 \\
\hline $\begin{array}{l}\text { Average } \\
\text { Nonstudious } \\
\text { Nonathletic }\end{array}$ & 11.85 & 8 & 14.00 & 8 & 6 \\
\hline
\end{tabular}

*Tannenbattm. 1960 
Anderson. 1971) to develop insights that would enable us to praise our friends so that others would like them. The not-too-surprising conclusion would seem to be that the best technique is to simply present them as positively as possible by attributing to them as many highly favorable things as you can think of.

Another question has received little, if any, attention. Could the same technique be used to present oneself to others? Would first-person praise or self-praise be as effective as third-person praise?

There would seem to be two main theories of personality impression formation relevant to such issues. One is the information integration model developed by Anderson (Anderson. 1971: Kaplan \& Anderson, 1971) and the other is the reinforcement model developed by Byrne (Byrne, 1969: Byrne \& Clore, 1970). Neither of these theories seems to make any specific prediction about first- vs third-person praise; but, more importantly, neither would seem in any way to deny the possibility that first-person praise might work. The empirical determination of the effectiveness of first-person praise would seem to be a most worthy research goal-one quite possibly to be undertaken by one or more of the present intelligent, sincere, truthful, warm, considerate, friendly, happy, optomistic, affirmative, energetic, lucky, earnest, and mature investigators.

\section{REFERENCES}

Anderson, N. H. Integration theory and attitude change. Psychological Review, 1971, 78, 171-206.

Byrne, D. Attitudes and attraction. In L. Berkowitz (Ed.), Advances in experimental social psychology. Vol. 4. New York: A cademic Press, 1969.

Byrne, D., \& Clore, G. L. A reinforcement model of evaluative responses. Personality, 1970, 1, 103-128.

Horowitz, H. Prediction of adolescent popularity and rejection from achievement and interest tests. Journal of Personality, $1967,58,170-174$.

Kaplan, M. F., \& Anderson, N. H. Comparison of information integration theory and reinforcement theory as approaches to interpersonal attraction. Technical Report No. 20, Center for Human Information Processing, Department of Psychology, University of California, La Jolla, California 92037.

Tannenbaum, A. J. Adolescents' attitudes toward academic brilliance. Unpublished doctoral dissertation, New York University, 1960.

Walker, H. M., \& Lev, J. Statistical inference. New York: Holt, 1953.

(Received for publication June 11, 1973.) 